COBISS: 1.08

\title{
MANAGEMENT ASSESSMENT IN KARST AREAS
}

\author{
OCENA UPRAVLJANJA S KRASOM
}

ELERY HAMILTON-SMITH, AM ${ }^{1}$

${ }^{1}$ Chair, IUCN/WCPA Task Force on Cave and Karst Protection, P.O. Box 36, Carlton South, VICTORIA 3053, AUSTRALIA. <elery@alexia.net.au>

Prejeto / received: 20. 2. 2002 


\section{Elery Hamilton-Smith: Ocena upravljanja s krasom}

Najpomembnejša odgovornost pri upravljanju s svetovno dediščino je dvojna. Po eni strani bi morali ohraniti integriteto in kakovost naravnega okolja, po drugi pa omogočiti dostop čim širši javnosti. Čeprav je v tej trditvi morda nekaj dvoumnosti pa ni dvoma, da se osnovna elementa tega vprašanja dopolnjujeta in da enega ni mogoče v celoti rešiti, ne da bi upoštevali tudi drugega. To vodi do ključnega vprašanja, ali je upravljalec sposoben odgovorno izvajati svoja pooblastila. Prispevek podaja pregled in ocene različnih splošnih pristopov k upravljanju, ki so bili oziroma bi lahko bili uporabljeni. To vključuje različne sheme nadzora nad vplivom obiskovalcev, v glavnem iz ZDA; gre za trojni (okoljski/družbeni/ekonomski) trajnostni pristop in tveganja pri upravljalski strategiji. Sklep prispevka je, da mora upravljalec vsakega kraškega področja razviti sprotno se dopolnjujoč načrt upravljanja, ki mora vključevati tako dolgoročne in načelne rešitve, obenem pa se mora ukvarjati tudi s posebnimi izzivi, ki so tipični le v lokalnem okviru. Vsak pristop, o katerem je govora v tem prispevku, lahko pomaga pri pripravi kateregakoli načrta upravljanja.

Ključne besede: krasoslovje, upravljanje s krasom.

\section{Abstract}

UDC: 504.06:65.012

\section{Elery Hamilton-Smith: Management Assessment in Karst Areas}

The key management responsibility in World Heritage Areas is a two-fold one of preserving environmental integrity and quality while at the same time providing for broad-scale public access. Although there is some ambiguity in this mandate, there is no question that these two elements of management are complementary, and that one cannot fully assess one without consideration of the other. This leads to the key question of how management is able to meet the responsibility of this mandate. This paper reviews and assesses various conceptual approaches that have been or might be utilised. These include various visitor impact control schemes generally of U.S. origin; the three faceted (environmental/social /economic) sustainability approach and risk management strategies. This paper concludes that each karst area management agency must develop an ongoing assessment plan that both deals with broad-scale issues while also meeting the distinctive challenges which are endemic to their own situation. Any of the approaches discussed may make a contribution to any one such plan.

Key words: karstology, karst management. 


\section{INTRODUCTION}

Inscription of any site on the World Heritage register essentially places the state party under two obligations. The first is to protect and maintain the integrity of the site, and the second is to make the site accessible and available to the peoples of the world. These dual and somewhat ambiguous obligations encapsulate the dilemma of all protected areas.

But this immediately highlights one of the major problems in existing monitoring programs. One only has to look at the content of this volume to see how much effort is devoted to the monitoring of various environmental parameters and how little is spent on issues of accessibility and quality of visitor experience. I do not, of course, devalue environmental issues - in fact, there is far too little being done. Moreover, far too much of what has been done is opportunistic rather than systematic. But the need for visitor monitoring demands systematic action virtually right across the world.

Even if an area does not enjoy World Heritage status, it is incumbent on managers of all protected areas to exercise proper stewardship over their estate. They should ensure not only protection of the estate as a whole, but the long-term preservation of both current values and potential future values. This in turn demands systematic monitoring and specific protective action as this is shown to be necessary.

The papers in this volume also point to another important quality of assessment and monitoring practice, namely, the fundamental knowledge-building role of all research. Some monitoring may be purely instrumental and serve only managerial objectives, but much of it produces deeper understandings of natural phenomena or stimulates the pursuit of new research questions.

\section{MONITORING IN CONTEXT}

Effective monitoring is not just a matter of measuring a series of variables. It demands an appropriate conceptual / theoretical basis so that we can place our measurements in some sort of framework. Perhaps this discussion should commence with a clarification of some terms. Natural area managers need to both understand the nature of the phenomena that impact upon the site for which they have responsibility, and similarly, to understand the impact of their own actions so that these may more effective address any problems. In order to achieve this understanding, they will usually need continuing systematic observation and measurement, and it is these processes of observation and measurement that are properly termed monitoring.

In other words, monitoring properly refers simply to the observation and measurement processes which occur within the broader process of assessment and knowledge building. To determine what parameters just be observed or measured demands a conceptual framework to identify the significant parameters (see Osborne, this volume) and determine how they might best be measured. Further, the results of observation and measurement do not in themselves provide understanding or knowledge, but only data from which understanding and knowledge can be built. This also demands a conceptual basis in order to maximise the understandings that we might derive from the data. 
Moreover, that basis should be a site-specific one, developed to meet the needs of managing the sites concerned. I have been centrally involved in developing two major programs of this kind - in the Australian Alps (Hamilton-Smith et al.1998) and at Jenolan Caves (Manidis Roberts 1995). The two programs are very different from each other, not only because each area has a distinctive set of environmental elements and visitor patterns, but also because each has a totally different management context. Further, the program developed at Jenolan (Hamilton-Smith 2000, Hamilton-Smith \& Ramsay 2001) is very different from that developed by colleagues at Waitomo Caves in New Zealand (Doorne 1998, Banbury 2000, Bunting \& Balks 2001)

In summary, the framework must inform the monitoring process in terms of at least how to:

- Best identify the elements of environment and of visitor experience which should be measured

- Carry out the actual measurement

- Interpret the results of measurement in terms of cause and effect

- Assess the significance of the measurements and their implications for management decisionmaking.

\section{SOME ISSUES AND PRINCIPLES}

Experience has convinced me that two of the most basic principles of good research, which I have tried to teach at the very beginning of my courses in research method, are that no phenomenon ever has only a single cause and no action ever has only a single outcome.

This is particularly true in the dynamic interaction of the diverse elements that make up any karst area. Hence another common saying amongst many of my colleagues who are responsible for management of karst areas - In karst, always expect the unexpected.

Caves and karst are complex. This complexity includes seasonal and other temporal variations, especially in high-energy systems. Similarly, any cave has a pattern of spatial variation, which often includes microclimatic and hence bio-environmental variation. In spite of some myths about uniformity of environment, think of the relatively small Cave of Early Man in Vietnam, with its seventeen species of bats and another Vietnamese cave with its 14 species of snails, 15 of which come from one family (Vermeulen \& Whitten 1999).

One further demand of our framework is that it will only be fully effective if it provides for a holistic view of the system being monitored. Quality measurement usually demands a systematic and sound approach based in the rigorous criteria of the relevant discipline, but then the overall framework must provide for understanding and integration across disciplinary boundaries $Đ$ those of us who have tried this know just how difficult it can be (Boulding \& Lundstedt 1998).

However, these scientific understandings must also be integrated with the on-ground knowledge of park staff, local residents and other stakeholders. It is all too easy for any one approach to knowledge building to totally miss what may well be almost self-evident to someone taking another approach. People with a lot of experience in a cave system may well recognize and be very familiar with sudden environmental changes (e.g., thermoclines, haloclines) which a scientist may well miss just by failing to locate instruments at the right spot. 


\section{A DIVERSITY OF MODELS}

General practice in monitoring of protected areas has been most strongly developed within the US Forest Service Research Stations and a number of Universities in North America. Probably the best-developed practice in relationship to karst protected areas has been in Italy, Australia and New Zealand. There are basically four groups of tools or models that have been variously used or advocated.

\section{- Visitor Impact systems}

These were the first models to be systematically developed, and represented a response to park managers who were concerned to establish a 'carrying capacity' for sites under their control or to find a means of assessing the need for management control of visitor behavior. They include the Limits of Acceptable Change Process (LAC) developed by Stankey and his colleagues (1985), the Visitor Impact Model (VIM) from Alan Graefe (1990) and the Visitor Experience and Resource Protection (VERP) system of Lime, Manning and the U.S. National Park Service (Belnap et al., 1997). These have progressively given increased emphasis to quality of visitor experience.

They have generally led to a valuable emphasis upon small but cumulative changes, precision of measurement, and are relatively easily understood by managers. But there are at least two major problems. One, abundantly demonstrated at the newly developed Kartchner Caverns in Arizona, U.S.A., is giving great emphasis to changes resulting from the entry of visitors (e.g., changes in humidity) while ignoring the enormous impacts of management actions. So, many hundreds (perhaps thousands) of tons of concrete have been imported into the cave to build massive pathway systems without any assessment of the consequent chemical reactions with the cave environment, to the inevitable changes in energy flows within the cave nor to the impacts upon many niches of distinctive microclimate.

The other is that these models have some difficulty in accommodating changes that have no relationship to visitors, and which may commonly result from off-site events, e.g., increases in sedimentation or pollution.

The concept of 'carrying capacity' has proven to be difficult to operationalise, and so the visitor impact models follow the direction of (a) defining objectives for environmental quality and visitor experience, (b) identifying themes and indicators to measure these, (c) measuring the extent to which the objectives are achieved, then (c) identifying and dealing with any shortfall.

\section{- Sustainability models}

The concept of sustainability in management of human activity has become an important direction in governmental policy in many sectors. It is based in attaining a viable inter-relationship and balance between social, environmental and economic outcomes.

Program models, which might be specifically applied in protected area management, do not appear to have been developed. However, the concept is widely used in decision-making in managing the multi-functional Biosphere Reserves. The concept can also be applied to some aspects of protected area management, and in particular to visitor (tourism) management. Thus, aspects of sustainability now appear in applications of the visitor impact models.

This serves to place monitoring within the broader socio-economic environment, to enhance 
consideration of long-term outcomes, and certainly to gain more political respect. The latter is, of course, a double-edged sword, and political-economic issues may come to over-ride environmental concerns and scientific method.

\section{- Risk Management Analysis}

Increasing awareness of risk, particularly the risks of public litigation, has drawn attention to the possibility using risk management as a tool in protected area management. Risk management identifies potential threats or threatening processes, then simply rates the likelihood of occurrence and the potential consequences. To take two examples:

- At Carlsbad Caverns WHA, the works depot for the park was located within the major catchment area that provides water to the caves system. It was realized that the possibility of a fire within the depot with its stores of hazardous chemicals represented a massive threat to the integrity of the cave system. Proper fire precautions against fire might well reduce the likelihood of such a fire, but the consequences would be catastrophic. After years of concern and demand, the park professionals have finally gained approval for removal and relocation of the depot.

- Interestingly, the contemporary epidemic of management restructuring has been seen as raising a very real threat of the loss of corporate memory. The likelihood is extremely high, but it has often been considered that there will also be beneficial outcomes and that any negative outcomes may be of little significance. However, this is not necessarily true. At Jenolan Caves, an investigation into traffic arrangements served to re-discover the inherent geological instability of the major access road and its history of major landslides. Then the Yucatán area of Mexico provided during the 1930s a classic textbook example of the dangers in discharging untreated sewerage into a karst aquifer (LaMoureaux 1999). However, over very recent years, this has been totally forgotten and multiple permits have been issued for large-scale resort hotels on the Riviera Maya coast. The consequences have become almost immediately visible, and are again, potentially catastrophic.

The value of the risk management approach lies in its capacity to help set priorities for both monitoring and action. It may lead to an undue focus on obvious and highly visible threats, even if the likely consequences are of lesser importance. Its effective application also demands a high degree of judgmental capacity.

\section{- Management Standards Approach}

With the development of international standards, and particularly ISO9000 with the associated ISO14000, it is likely that much more attention will be given to monitoring. It is too early yet to fully consider the implications for protected area management, but it will probably lead to

- Monitoring and assessment being effectively embedded into the overall structure and processes of management

- More emphasis being given to systematic and integrated knowledge management

But there are the new threats of

- Monitoring and assessment focusing more upon the demands of the managerial structure rather than those of the environment and visitors

- Undue emphasis being placed upon simplistic quantification 


\section{CONCLUSION}

As emphasised at the beginning, site assessment planning should be based in the values and characteristics of the site and its management.

But I trust we will continue to experiment and learn. Certainly at Jenolan Caves, we have commenced with the VIM approach, gradually given increasing attention to sustainability, particularly in relation to tourism management, and have carried out a risk management assessment. With recent changes in the membership of the board and restructuring of management, we can look forward to greater integration with management.

But it all depends upon recognition of the importance of proper assessment and control of protected areas management and gaining a commitment from governments to provide adequate resources for the management of protected areas. Hopefully, World Heritage Areas will be able to lead the way.

\section{REFERENCES}

Banbury, K., 2000: Research Side of things at Waitomo's Glowworm Cave. Australasian Cave and Karst Management Association Journal, 39: 19.

Belnap, J. et al., 1997. VERP: The Visitor Experience and Resource Protection Framework. USDI National Park Service, Denver, CO.

Boulding, K.E. \& Lundstedt, S.B., 1998: Value Concepts and Justifications, in Peterson, G.L., Driver, B.L. \& Gregory, R. (eds.) Amenity Resource Valuation, Integrating Economics with Other Disciplines. Venture Publishing Inc., State College, PA. pp. 13-21.

Bunting, B. \& Balks, M., 2001: A Quantitative Method for Assessing the Impacts of Recreational Cave Use on the Physical Environment of Wild Caves. Australasian Cave and Karst Management Association Journal, 44: 10-18.

Doorne, S. 1998: Analysing the Visitor Experience: Issues and Implications from a Study of Crowding and Cultures at the Waitomo Glowworm Cave. Cave and Karst Management in Australasia, XII: 75-84.

Graefe, Alan R, Fred R Kuss \& Jerry J Vaske 1990: Visitor Impact Management : The Planning Framework. National Parks and Conservation Association, Washington, DC.

Hamilton-Smith, E. 2000: Managing for Environmental and Social Sustainability at Jenolan Caves, New South Wales, Australia. in Barany-Kevei, I. \& Gunn, J. (eds.), Essays in the Ecology and Conservation of Karst, Acta Geographica Szegedensis, 36: 144-152.

Hamilton-Smith, E.\& Ramsay, A., 2001: Social and Environmental Evaluation at Jenolan Caves, New South Wales. Evaluation Journal of Australia, n.s., 1: 60-65.

Hamilton-Smith, E, Sandells, P. \& Williamson, D.1998: Managing Recreational Environments : Towards a strategy for the Australian Alps national parks. Rethink Consulting P/L for the Australian Alps Liaison Committee. Melbourne, Australia.

LaMooreaux, P. E., 1999: Overview of the History of Karst Hydrogeological Studies, in Drew, D.\& Hotzl, H. (eds.), Karst Hydrogeology and Human Activities. Balkema, Rotterdam.

Manidis Roberts Consultants 1995: Determining an Environmental and Social Carrying Capacity for Jenolan Caves Reserve. Manidis Roberts Consultants for Jemolan Caves Reserve Trust. Sydney, Australia. 
Stankey, George H., David N. Cole, Robert C. Lucas, Margaret E. Petersen \& Sidney S. Frissell. 1985: The Limits of Acceptable Change (LAC) System for Wilderness Planning. USDA Forest Service, Intermountain Forest and Range Experiment Station, General Technical Report INT-176.

Vermeulen, J. \& Whitten, T., 1999: Biodiversity and Cultural Property in the Management of Limestone Resources. World Bank, New York.

\section{OCENA UPRAVLJANJA S KRASOM}

\section{Povzetek}

Zanimanje za razvoj in vzdrževanje kakovosti upravljanja s kraškimi področji, predvsem v povezavi s svetovno dediščino, pridobiva na pomembnosti. Prispevek odkriva in ocenjuje različne konceptualne pristope, ki so ali so bili do sedaj v uporabi.

Glavna odgovornost upravljanja je dvojna, včasih celo dvoumna; na eni strani naj bi ohranili integriteto in kakovost okolja, na drugi strani pa omogočili dostop čim širši javnosti. To vodi do ključnega vprašanja, ali je uprava sposobna odgovorno izvajati svoja pooblastila.

Precejšnja pozornost je bila posvečena različnim shemam za ugotavljanje vpliva obiskovalcev (LAC, VIM, VERP in drugih) na jamsko okolje, običajno ameriškega izvora; kasneje so bile te metode razvite $v$ tri izbrušene (okolje/družba/gospodarstvo) trajnostne pristope. Uporabljena je bila tudi strategija upravnega tveganja tako v okviru drugih pristopov kot neodvisno za osnovo pri določanju vrstnega reda nujnih ukrepanj. Končno, uprava lahko uporablja kot svojo osnovo standarde ISO9000/ISO14000.

Prispevek zaključuje, da mora vsaka organizacija na kraškem področju razviti načrt upravljanja in ukrepanja, ki predvideva splošne cilje, obenem pa mora upoštevati tudi posebne izzive, ki jih narekuje njihov posebni položaj. Vsak od omenjenih pristopov lahko prispeva k takemu načrtu. 